\title{
KEUNGGULAN BERSAING DAN PENCIPTAAN NILAI PADA PERUSAHAAN MANUFAKTUR YANG TERDAFTAR DI BURSA EFEK INDONESIA
}

\author{
Sri Rani Fauziah (rani_fauziah@yahoo.com) \\ Politeknik Aceh \\ I Made Sudana (imadesudana@yahoo.co.id) \\ Departemen Manajemen Fakultas Ekonomi dan Bisnis Universitas Airlangga
}

\begin{abstract}
Resources, capabilities and core competencies are the basic characteristics of the competitive advantage. How resources and capabilities for the long time can contribute to creating value to the company and be able to compete in the industry, it is difficult to measure. The prupose of the research is to examine the affect of competitive advantage which consists of customer relationship, supplier relationship, intellectual property and fixed asset management on creating value for the manufacture companies using financial ratio analysis. This research using panel data to investigate 58 companies listed in Indonesia Stock Exchange (BEI) in the year 2008-2011. The results show that the relationship with suppliers, intellectual property and fixed asset management, can increase creating value for the manufacture companies that listed in BEI.
\end{abstract}

Keywords: Competitive advantage, customer relationship, supplier relationship intellectual property,fixed asset management and creating value.

\section{PENDAHULUAN}

Pertumbuhan industri manufaktur di Indonesia akhir-akhir ini semakin pesat. Hal ini dapat dilihat dari pertumbuhan produksi industri manufaktur selama tahun 2008-2011 yang mengalami pertumbuhandari $4,45 \%$ pada tahun 2010 menjadi $5,56 \%$ pada tahun 2011 , sedangkan pada tahun 2009 pertumbuhan produksi hanya sebesar 1,34\% sedikit mengalami penurunan dibandingkan tahun 2008 sebesar 3.01\% (www.bps.go.id). Hal ini terjadi karena krisis ekonomi global yang terjadi pada tahun 2008 dan secara riil dampaknya terhadap industri manufaktur di Indonesia terjadi pada 2009. Jumlah perusahaan manufaktur yang terdaftar di Bursa Efek Indonesia juga terus mengalami peningkatan dari tahun 2008 sebanyak 126 perusahaan menjadi 134 perusahaan tahun 2011 (www.idx.co.id). Hal ini mengindikasikan semakin banyaknya dana yang dibutuhkan dalam menunjang perkembangan industri manufaktur. Perkembangan perusahaan manufaktur juga meningkatkan persaingan di dalam industri tersebut. Hal ini juga dipicu oleh masuknya berbagai produk impor, baik yang legal maupun ilegal. Kondisi ini mengharuskan perusahaan untuk selalu meningkatkan daya saingnya. Masuknya berbagai produk impor barang-barang yang sudah dihasilkan di dalam negeri mengindikasikan bahwa perusahaan manufaktur di Indonesia kalah bersaing dengan perusahaan manufaktur di luar negeri.

Sumber daya, kemampuan dan kompetensi utama merupakan karakteristik dasar dalam keunggulan bersaing (Kuncoro, 2006:38). Sumber daya perusahaan dapat diklasifikasikan menjadi dua yaitu sumber daya berwujud (tangible) dan sumber daya tidak berwujud (intangible). Sumber daya berwujud seperti pabrik dan perlengkapan produksi yang dikelola 
dengan efisien dapat menciptakan produk dengan harga yang lebih rendah. Sementara itu, sumber daya tidak berwujud dapat dibagi lagi dalam sumber daya relasional dan kompetensi. Sumber daya ralasional timbul dari hubungan perusahaan dengan pelanggan dan pemasok. Menjalin hubungan yang berkesinambungan dengan pemasok dapat menjamin ketersediaan sumber daya produksi secara terus menerus, sehingga perusahaan dapat memenuhi permintaan pelanggan.

Menurut Hitt et al (2005:119), kombinasi sumber daya dan kapabilitas akan dapat meningkatkan daya saing yang strategis dan berkontribusi pada penciptaan nilai bagi perusahaan. Penciptaan nilai merupakan sumber potensial perusahaan untuk mendapatkan pengembalian di atas rata-rata, yang pada akhirnya akan memerikan keuntungan bagi pemegang saham perusahaan.

Return of Invested Capital (ROIC) sering digunakan sebagai salah satu proksi untuk menilai kemampuan perusahaan dalam menciptakan nilai melalui kinerja keuangan. Return of Invested Capital (ROIC) pada perusahaan manufaktur yang terdaftar di Bursa Efek Indonesia pada tahun 2008 sampai 2011 sangat berfluktuatif dengan rata-rata ROIC berkisar antara 12\% sampai $15 \%$.

Dalam penelitian Liou et.al (2009), menyatakan bahwa perusahaan yang memiliki intellectual property yang tinggi dan pengelolaan fixed asset yang baik dan efisien dapat meningkatkan penciptaan nilai bagi perusahaan dan pemegang saham, sedangkan menurut Liou dan Gao (2011), keunggulan bersaing sangat ditentukan oleh intellectual property dan relationship with supplier. Relationship with supplier merupakan kekuatan perusahaan dalam meningkatkan likuiditas, yang ditandai dengan tingginya cash turnover, account receivable turnover yang rendah dan account payabel turnover yang tinggi.

Penelitian ini menjelaskan tentang pengaruh keunggulan bersaing yang terdiri atas customer relationship, supplier relationship, intellectual property dan fixed asset management, yang diproksikan dengan rasio-rasio keuangan terhadap penciptaan nilai perusahaan yang diproksikan dengan return on invested capital (ROIC).

\section{LANDASAN TEORI DAN PENGEMBANGAN HIPOTESIS}

\section{Pengertian dan Pengukuran Keunggulan Bersaing}

Banyak pandangan yang telah dikemukakan oleh para peneliti dalam menciptakan keunggulan bersaing perusahaan. Porter (2008) yang dikenal dengan Five Force Model, mengemukakan bahwa keunggulan bersaing adalah kemampuan perusahaan untuk menghasilkan return dari investasi secara konsisten lebih tinggi dari rata-rata return industri.

Menurut Barney (2012:28), yang dikenal dengan Resources Based View (RBV), menyatakan bahwa keunggulan bersaing dapat dicapai apabila strategi penciptaan nilai yang diimplementasikan oleh perusahaan, secara simultan tidak dapat diimplementasikan oleh pesaing. Brockbank dan Urlich (2005:6), menyatakan bahwa keunggulan bersaing muncul ketika sebuah perusahaan mampu melakukan sesuatu yang unik, sedangkan menurut Hitt et.al (2005:5), perusahaan memiliki keunggulan bersaing ketika perusahaan dapat mengimplementasikan suatu strategi dan perusahaan lain tidak dapat memalsukannya atau akan memerlukan biaya yang besar untuk dapat melakukan replikasi. Menurut Ismail Solihin 
(2012: 50), keunggulan bersaing perusahaan dapat dicapai apabila perusahaan memiliki diferensiasi produk dengan biaya yang lebih rendah dibanding pesaing.

Salah satu cara yang digunakan untuk mengukur keunggulan bersaing adalah malalui rasio keuangan. Rasio keuangan adalah sebuah indeks yang menghubungkan dua angka akuntansi dan didapat dengan membagi satu angka dengan angka lainnya. (Horne,2009:202). Rasio keuangan dapat mencerminkan berbagai strategi yang diterapkan perusahaan untuk mencapai tujuannya, yaitu menciptakan nilai bagi perusahaan.

\section{Pengertian dan Pengukuran Penciptaan Nilai}

Penciptaan nilai (creating value) bagi perusahaan terjadi ketika perusahaan mampu menghasilkan sesuatu yang lebih dari sumber daya yang diinvestasikan. Dengan kata lain, apabila perusahaan mampu mengelola dan memanfaatkan sumber daya yang dimiliki, sehingga sumber daya tersebut dapat menciptakan value added bagi perusahaan, dan hal ini disebut sebagai value creation. Perusahaan menciptakan nilai bagi pelanggan dengan menawarkan produk yang terbaik dengan harga yang lebih rendah dibandingkan dengan pesaing.. Perusahaan menciptakan nilai dalam hubungannya dengan pemasok, apabila perusahaan mendapatkan harga yang lebih rendah melalui hubungan baik dan kerjasama yang berkelanjutan dengan pemasok. Hal ini akan menciptakan nilai bagi perusahaan dan pemegang saham berupa pendapatan yang lebih tinggi (Spulber, 2009:15). Menurut Bowman (2007), terdapat 3 aktivitas dalam proses penciptaan nilai, yaitu penciptaan barang atau jasa, merealisasikan pendapatan dari pelanggan dan meminimalisasi biaya dari pemasok. Barney (2012:113) menyatakan bahwa dengan sumber daya yang unik, kekuatan hubungan antara perusahaan dengan pelanggan dan pemasok yang dapat menciptakan nilai bagi perusahaan, menunjukan perusahaan memiliki keunggulan bersaing. Nilai perusahaan dapat dijelaskan dari nilai buku yang dihitung dengan dasar konsep akuntansi.

Return of Invested Capital (ROIC) merupakan salah satu indikator yang digunakan untuk menukur efektivitas pemanfaatan sumber daya dan kapabilitas perusahaan dalam menciptakan nilai yang tercermin dalam kinerja keuangan perusahaan. Menurut Koller et.al (2005:61), ROIC menunjukkan tingkat efisiensi penggunaan dan pengalokasian sumber daya perusahaan dan tingkat efektivitas pengaturan dan pengelolaan sumber daya perusahaan. Perusahaan yang memiliki ROIC yang tinggi akan mampu meningkatkan pendapatan yang menghasilkan total return kepada pemegang saham (Jiang and Koller, 2007), sehingga lebih mampu dalam bersaing (Tang \& Liou, 2010). Dengan demikian, perusahaan yang menghasilkan ROIC yang lebih tinggi dari rata-rata industri, memiliki keunggulan bersaing karena dapat menghasilkan revenue dan return yang tinggi, sehingga dapat menciptakan nilai bagi perusahaan dan pemegang saham.

Besar kecilnya ROIC diukur dengan persamaan sebagai berikut (Tang \& Liou, 2010 dan Brigham, 2004: 293):

$$
\begin{aligned}
\text { ROIC }= & \frac{\text { NOPLAT }}{\text { Invested Capitai }} \\
& =\frac{\text { NOPLAT }}{S} \chi \frac{S}{\text { Invested Capital }} \\
& =\frac{(S-C G S-R \& D-D E P-S G \& A-T A X) / S}{C A S H+A R+I N V+F A-(A P+A C C R) / S}
\end{aligned}
$$


Keterangan:

$\begin{array}{ll}\text { NOPLAT } & =\text { Net Operating Profit Less Adjusted Taxes } \\ S & =\text { Sales } \\ C G S & =\text { Cost of Good Sold } \\ R \& D & =\text { Research and Development Expenses } \\ \text { Dep } & =\text { Depreciation } \\ S G \& A & =\text { Selling, General and Administration expenses } \\ F A & =\text { Fixed Assets } \\ A R & =\text { Account Receivable } \\ \text { Inv } & =\text { Inventory } \\ \text { AP } & =\text { Account Payable } \\ A C C R & =\text { Accrual expenses }\end{array}$

Terdapat beberapa faktor yang memengaruhi perusahaan dalam penciptaan nilai. Tang \& Liou (2009) mengklasifikasikan faktor-faktor yang mempengaruhi perusahaan dalam penciptaan nilai berdasarkan rasio aktivitas, yaitu Customer Relationship, Supplier relationship, Intdellectual property dan fixed asset management

\section{Customer Relationship}

Strategi bersaing bertujuan untuk menumbuhkan penciptaan nilai melalui hubungan dengan pelanggan. Untuk mencapai keunggulan bersaing, perusahaan harus mampu meningkatkan keuntungan bagi pelanggan, memberikan produk yang inovatif dengan harga yang lebih rendah. Meningkatkan nilai bagi pelanggan berarti membangun hubungan baik dengan pelanggan dalam jangka panjang (Kotler, 2007:187). Semakin tinggi kepuasan pelanggan yang dapat diberikan oleh perusahaan, maka semakin tinggi pula tingkat pengembalian yang mungkin diperoleh perusahaan. Salah satu cara untuk membina hubungan baik dengan pelanggan adalah dengan memberikan informasi kepada pelanggan melalui kegiatan periklanan. Customer Relationship diukur dengan menggunakan rasio Sales / Advertising expenses dan Receivable turnover.

Biaya advertising merupakan biaya yang dikeluarkan perusahaan dalam rangka untuk memasarkan produknya. Tujuannya adalah untuk promosi guna meningkatkan volume penjualan (Chen et. al, 2005). Iklan yang efektif dan tepat sasaran dapat meningkatkan animo dan loyalitas pelanggan terhadap produk perusahaan sehingga perusahaan dapat memiliki keunggulan bersaing dan meningkatkan nilai perusahaan dan pemegang saham.

$\mathrm{H}_{1}$ : Customer relationship yang diukur dengan sales/advertising berpengaruh positif terhadap creating value (ROIC).

Account receivable turnover merupakan rasio untuk mengukur perputaran piutang dalam menghasilkan penjualan. Semakin tinggi perputaran piutang berarti semakin efektif dan efisien manajemen piutang yang dilakukan perusahaan (Sudana, 2011:22). Perputaran piutang tidak terlepas dari kebijakan kredit perusahaan yang diberikan kepada pelanggan. Perusahaan yang memiliki perputaran piutang rata-rata lebih tinggi dibandingkan rata-rata industri, mengindikasikan bahwa perusahaan tersebut memiliki hubungan baik dengan pelanggan, sehingga perputaran piutangnya tinggi atau penagihan piutangnya lancar. Dengan 
kata lain perusahaan memiliki keunggulan bersaing yang lebih baik dan lebih mampu untuk menciptakan nilai bagi perusahaan.

$\mathrm{H} 2$ : Customer relationship yang diukur dengan account receivable turnover berpengaruh positif terhadap creating value (ROIC)

\section{Supplier Relationship}

Pemasok merupakan hal penting dalam kelangsungan operasional perusahaan, karena dapat membantu menjamin keberlanjutan ketersediaan bahan baku sesuai kebutuhan perusahaan dalam produksi (Hitt, et al, 2005:161). Persediaan bahan baku yang berlebihan akan menimbulkan biaya penyimpanan yang tidak efisien. Konsep pengelolaan persediaan berdasarkan Just In Time (JIT), merupakan pendekatan manajemen persediaan dengan meminimalkan biaya penyimpanan, yang dilakukan dengan mengurangi persediaan sampai titik nol (Simchi.et.al, 2008:321). Hal ini dapat dicapai apabila perusahaan dapat membangun dan menjalin hubungan baik dalam jangka panjang dengan pemasok. Supplier relationship diukur dengan menggunakan account payable turnover, inventory turnover dan sales/cost of good sold

Account payable turnover mengukur bagaimana manajemen perusahaan mengelola pembayaran utang kepada pemasok. Perusahaan yang memiliki hubungan yang baik dengan pemasok, akan dapat memperoleh kemudahan berkaitan dengan memperpanjang periode pembayaran. Apabila pembayaran utang dagang dapat ditunda, maka tambahan modal yang dimiliki dapat digunakan untuk biaya operasional lainnya. Di samping itu, perusahaan yang dapat menjalin hubungan baik dengan supplier akan memengaruhi ketersediaan bahan baku dari supplier sesuai dengan kebutuhan perusahaan, sehingga proses produksi dapat berjalan dengan lancar. Hal ini berarti bahwa perusahaan memiliki keunggulan bersaing karena dapat menyediakan produk lebih cepat dari pada pesaing.

H3: Supplier relationship yang diukur dengan account payable turnover berpengaruh negatif terhadap creating value (ROIC).

Inventory turnover mengukur perputaran persediaan dalam menghasilkan penjualan. Semakin tinggi rasio ini semakin efektif dan efisien pengelolaan persediaan oleh manajemen perusahaan untuk menghasilkan penjualan (Sudana, 2011:21). Persediaan bahan baku merupakan elemen utama dari produksi yang selalu berputar. Besarnya investasi atau alokasi dana dalam persediaan mempunyai dampak pada cash flow dan keuntungan perusahaan (Brigham \& Daves, 2004:233). Ketersediaan persediaan yang cukup dapat dicapai apabila perusahaan dapat berkerjasama dengan pamasok agar rantai pasokan dapat berjalan lancar dan tepat waktu.. Dengan demikian perusahaan akan memeiliki keunggulan bersaing dan mampu menciptakan nilai yang lebih tinggi.

H4: Supplier relationship yang diukur dengan inventory turnover berpengaruh positif terhadap creating value (ROIC).

Rasio ketiga yang digunakan untuk mengukur keunggulan bersaing dalam supplier relationship adalah rasio Sales/Cost of Good Sold. Menurut Vance (2003:3) cost of gold sold merupakan semua biaya yang dikeluarkan dalam rangka menciptakan produk dan siap untuk dijual kepada palanggan. Semakin tinggi rasio ini menunjukkan bahwa manajemen telah 
mampu melakukan efisiensi biaya produksi dengan baik. Menjaga hubungan dengan pemasok merupakan hal yang penting bagi perusahaan, karena kualitas barang dan jasa yang tawarkan kepada pelanggan dipengaruhi oleh kualitas bahan dan jasa yang di tawarkan oleh pemasok (Spulber, 2009:100). Dengan demikian, rasio sales/cost of good sold yang tinggi dapat dicapai apabila perusahaan memiliki hubungan baik dengan supplier. Perusahaan harus melakukan efisiensi biaya produksi agar dapat menghasilkan produk yang lebih murah daripada yang ditawarkan oleh pesaing, sehingga perusahaan dapat menciptakan keunggulan bersaing. Hal ini tentu saja akan meningkatnya penjualan dan diharapkan dapat meningkatkan laba perusahaan. Dengan demikian tujuan manajemen untuk dapat meningkatkan nilai bagi perusaahan dan pemegang saham dapat tercapai.

H5: Supplier relationship yang diukur dengan sales/cost of good sold berpengaruh positif terhadap creating value (ROIC)

\section{Intellectual property}

Menurut Lev dan Zambon (2003), Intellectual property as non-monetary assets or resources without physical substance, such as innovation, knowledge, research and development, employee training or customer satisfaction, underlying a firm's value creation process. Intellectual property merupakan sumber daya yang unik sehingga tidak semua perusahaan dapat menirunya. Hal inilah yang menjadikan intellectual property sebagai sumber daya kunci bagi perusahaan untuk menciptakan value added dan menciptakan keunggulan bersaing perusahaan. Perusahaan yang memiliki keunggulan bersaing tentunya akan mampu bertahan di lingkungan bisnis yang makin berkembang, sehingga tujuan perusahaan untuk memaksimumkan nilai bagi perusahaan dan pemegang saham dapat terwujud. Intellectual property diukur dengan menggunakan rasio biaya penjualan,umum dan administrasi terhadap penjualan. Hal ini karena dalam biaya umum administrasi dan penjualan mencakup biaya pendidikan dan pelatihan bagi para karyawan, sebagai salah satu upaya perusahaan untuk meningkatkan intellectual propertiy perusahaan.

Rasio Selling, general \& administration expense /Sales yang semakin kecil menunjukkan bahwa perusahaan mampu mengelola biaya penjualan, umum dan administrasi dengan efisien. Biaya penjualan, umum dan administrasi (SG\&A expenses) adalah semua biaya operasional selain biaya harga pokok penjualan (Vance, 2003:189). Biaya ini merupakan biaya yang paling mungkin dapat dikurangi tanpa memengaruhi proses produksi.Perusahaan yang dapat memperkecil biaya SG\&A seperti employees' skill dan licensing right (Gao, 2011) melalui pengawasan yang ketat dan terus menerus dapat meningkatkan laba perusahaan lebih besar dari pada perusahaan pesaing yang memilki tingkat pertumbuhan penjualan yang sama. Dengan demikian perusahaan memiliki keunggulan bersaing dalam industri yang pada akhirnya akan menciptakan nilai bagi perusahaan dan pemegang saham.

H6: Intellectual property yang diukur dengan selling, general \& administration/sales berpengaruh negatif terhadap creating value (ROIC).

\section{Fixed asset management.}

Salah satu sumber daya perusahaan yang digunakan dalam proses produksi yang memerlukan pengeluaran dan investasi yang besar dalam perusahaan manufaktur adalah fixed asset. Fixed asset merupakan sumber daya berwujud (tangible), yaitu segala sesuatu yang tersedia di 
perusahaan yang secara fisik dapat dilihat seperti bangunan, mesin, tanah dan sebagainya (Solihin, 2012:51). Fixed asset mempunyai masa manfaat lebih dari satu tahun, sehingga penanaman modal dalam aset tetap merupakan investasi jangka panjang, dan membutuhkan pertimbangan yang teliti baik dalam hal pembelian maupun dalam biaya pemeliharaan yang diperlukan dalam operasional aset tersebut (Syamsuddin, 2001: 408).. Semakin efisien perusahaan dalam mengelola aset tetap, maka semakin tinggi peluang perusahaan untuk menghasilkan pendapatan dan semakin tinggi pula kemampuan perusahaan untuk menciptakan nilai bagi perusahaan. Fixed asset mangement diukur dengan menggunakan rasio Sales / Depreciation dan fixed asset turnover

Rasio Sales/Depreciation menunjukkan seberapa besar jumlah penjualan dapat menutupi biaya penyusutan aset tetap.. Semakin tinggi rasio ini menunjukkan bahwa menejemen mampu mengelola biaya penyusutan aset tetap yang dialokasikan pada harga pokok penjualan lebih efisien. Hal ini dapat dicapai jika volume produksi dan penjualan dapat ditingkatkan dengan biaya penyusutan yang tetap. Hal ini biya dicapai jika perusahaan dapat mengoptimalkan pemanfaatan aset tetap. Kondisi ini memungkinkan perusahaan memiliki keunggulan bersaing karena dapat memberikan harga jual lebih rendah dari pada yang ditawarkan oleh pesaing. Dengan demikian, tujuan perusahaan selain untuk memberikan kepuasan kepada pelanggan, perusahaan juga dapat menciptakan nilai bagi pemegang saham.

H7: Fixed asset management yang diukur dengan sales/depreciation berpengaruh positif terhadap creating value (ROIC).

Rasio fixed asset turnover mengukur efektifitas penggunaan aset tetap untuk menghasilkan penjualan bagi perusahaan (Sudana, 2011:22). Semakin tinggi rasio fixed asset turnover, menunjukkan semakin efisien perusahaan dalam mengelola investasi pada aset tetap untuk menghasilkan penjualan. Sebaliknya, rasio fixed asset turnover yang rendah, berarti bahwa perusahaan telah melakukan investasi yang berlebihan dalam aset tetapnya. Perusahaan dikatakan memiliki efisiensi lebih tinggi dalam mengelola aktiva tetap dibandingkan dengan perusahaan lainnya, jika perusahaan memiliki rasio perputaran aset tetap lebih tinggi dari rata-rata industri (Brigham, 2005:99). Perusahaan yang mampu meningkatkan penjualan dengan investasi yang kecil pada aset tetapnya menunjukkan bahwa perusahaan mampu menciptakan keunggulan bersaing, sehingga pada akhirnya mampu menciptakan nilai bagi perusahaan dan pemegang saham (Lin \& Huang, 2011).

H8: Fixed asset management yang diukur dengan fixed asset turnover berpengaruh positif terhadap creating value (ROIC).

\section{MODEL ANALISIS}

Untuk menganalisis pengaruh keunggulan bersaiang terhadap penciptaan nilai bagi perusahaan, digunakan model analisis regresi berganda data panel sebagai berikut:

$$
\begin{aligned}
R O I C_{i t}=\propto_{0}+ & \beta_{1}\left(\frac{S_{i t}}{A D V_{i t}}\right)+\beta_{2} A R T_{i t}+\beta_{3}\left(\frac{S_{i t}}{C G S_{i t}}\right)+\beta_{4} A P T_{i t}+\beta_{5} I N V T+\beta_{6}\left(\frac{R \& D_{i t}}{S_{i t}}\right) \\
& +\beta_{7}\left(\frac{S G \& A_{i t}}{S_{i t}}\right)+\beta_{8} F A T_{i t}+\beta_{9}\left(\frac{S_{i t}}{D e p_{i t}}\right)+\varepsilon_{i t}
\end{aligned}
$$


Keterangan:

$\begin{array}{ll}R O I C_{i t} & =\text { Return on invested capital perusahaan } i \text { tahun } t \\ A D V_{i t} & =\text { Advertising expenses perusahaan i tahun } t \\ A R T_{i t} & =\text { Account receivable turnover perusahaan } i \text { tahun } t \\ C G S_{i t} & =\text { Cost of good sold perusahaan } i \text { tahun } t \\ S_{i t} & =\text { Sales perusahaan } i \text { tahun } t \\ A P T_{i t} & =\text { Account payable turnover perusahaan } i \text { tahun } t \\ I N V T_{i t} & =\text { Inventory turnover perusahaan } i \text { tahun } t \\ R \& D_{i t} & =\text { Research and development perusahaan } i \text { tahun } t \\ S G \& A_{i t} & =\text { Selling, general and administration perusahaan } i \text { tahun } t \\ F A T_{i t} & =\text { Fixed asset turnover perusahaan } i \text { tahun } t \\ D e p_{i t} & =\text { Depreciation perusahaan } i \text { tahun } t\end{array}$

\section{HASIL DAN PEMBAHASAN}

\section{Diskripsi Variabel}

Adapun variabel yang ditelti adalah: customer relationship yang diproksikan dengan rasio sales/advertising expenses dan account receivable turnover (ART);supplier relationship rasio account payabel turnover (APT), rasio sales/cost of good sold (CGS) dan inventory turnover (INVT); intellectual property (IP) yang diiukur dengan menggunakan rasio selling, general and administration expenses (SGA)/sales dan fixed asset management (FAM) yang diukur dengan menggunakan rasio fixed asset turnover (FAT) dan rasio sales/depresiation $(D E P)$.

Pada Tabel 1. dipaparkan deskripsi dari masing-masing variabel yang diteliti sebagai berikut:

Tabel 1. Diskripsi Variabel

\begin{tabular}{|c|c|c|c|c|c|c|}
\hline \multicolumn{3}{|c|}{ Keterangan } & 2008 & 2009 & 2010 & 2011 \\
\hline \multirow{8}{*}{$\begin{array}{l}\text { Customer } \\
\text { Relationship } \\
\text { (CR) }\end{array}$} & \multirow{4}{*}{ SALES/ ADV } & Rata-rata & $1.414,46$ & $1.028,12$ & 976,78 & $2.471,69$ \\
\hline & & SD & $4.364,72$ & $2.416,61$ & $2.678,60$ & $7.786,67$ \\
\hline & & Max & $25.667,06$ & $10.354,38$ & $15.654,76$ & $41.415,53$ \\
\hline & & Min & 4,67 & 4,96 & 4,64 & 4,59 \\
\hline & \multirow{4}{*}{ ART } & Rata-rata & 13,79 & 10,21 & 8,51 & 9,25 \\
\hline & & SD & 33,90 & 11,65 & 7,58 & 9,12 \\
\hline & & Max & 260,88 & 78,57 & 50,65 & 59,30 \\
\hline & & Min & 1,82 & 1,06 & 1,44 & 1,90 \\
\hline \multirow{6}{*}{$\begin{array}{c}\text { Supplier } \\
\text { Relationship }\end{array}$} & \multirow{4}{*}{ APT } & Rata-rata & 22,60 & 15,95 & 18,22 & 13,65 \\
\hline & & SD & 33,60 & 14,45 & 19,64 & 12,50 \\
\hline & & Max & 165,33 & 78,00 & 108,75 & 61,31 \\
\hline & & Min & 3,71 & 2,30 & 2,60 & 3,00 \\
\hline & \multirow{2}{*}{ SALES/CGS } & Rata-rata & 1,39 & 1,43 & 1,45 & 1,45 \\
\hline & & SD & 0,37 & 0,39 & 0,42 & 0,46 \\
\hline
\end{tabular}




\begin{tabular}{|c|c|c|c|c|c|c|}
\hline \multirow[t]{6}{*}{ (SP) } & & $\operatorname{Max}$ & 2,83 & 2,88 & 2,91 & 3,30 \\
\hline & & Min & 0,95 & 0,98 & 1,06 & 1,06 \\
\hline & \multirow{4}{*}{ INVT } & Rata-rata & 7,01 & 7,84 & 7,46 & 6,97 \\
\hline & & SD & 3,68 & 5,97 & 4,50 & 4,30 \\
\hline & & Max & 16,98 & 39,83 & 25,77 & 25,91 \\
\hline & & Min & 0,82 & 1,45 & 1,48 & 0,35 \\
\hline \multirow{4}{*}{$\begin{array}{c}\text { Intellectual } \\
\text { Property (IP) }\end{array}$} & \multirow{4}{*}{ SGA/SALES } & Rata-rata & 0,16 & 0,15 & 0,16 & 0,15 \\
\hline & & SD & 0,12 & 0,10 & 0,12 & 0,11 \\
\hline & & Max & 0,57 & 0,48 & 0,50 & 0,49 \\
\hline & & Min & 0,03 & 0,04 & 0,03 & 0,02 \\
\hline \multirow{8}{*}{$\begin{array}{l}\text { Fixed Asset } \\
\text { Management } \\
\text { (FAM) }\end{array}$} & \multirow{4}{*}{ FAT } & Rata-rata & 7,10 & 6,18 & 6,06 & 5,64 \\
\hline & & SD & 10,03 & 10,78 & 6,60 & 4,66 \\
\hline & & Max & 59,35 & 81,70 & 35,70 & 26,34 \\
\hline & & Min & 0,52 & 0,46 & 0,55 & 0,50 \\
\hline & \multirow{4}{*}{ SALES/DEP } & Rata-rata & 52,63 & 47,76 & 51,68 & 54,79 \\
\hline & & SD & 37,96 & 47,70 & 46,91 & 43,59 \\
\hline & & Max & 173,36 & 338,40 & 282,33 & 214,27 \\
\hline & & Min & 5,86 & 6,84 & 7,63 & 8,18 \\
\hline
\end{tabular}

Sumber: Hasil Pengolahan Data

\section{Analisis dan Pembuktian Hipotesis}

Hasil analisis pengaruh competitive advantage terhadap creating value, yang diproksikan dengan customer relationship (CR), supplier relationship (SR), intellectual property (IP) dan fixed asset management (FAM) dengan masing-masing alat ukurnya, dipaparkan pada Table 2.

Tabel 2. Hasil Regresi Data Panel dengan Metode REM

\begin{tabular}{|l|c|c|c|c|}
\hline \multirow{2}{*}{$\begin{array}{c}\text { Customer } \\
\text { Relationship }\end{array}$} & Variable & Coefficient & Prob. & Keterangan \\
\hline \multirow{3}{*}{ Supplier Relationship } & Sales/ADV & $1.17 \mathrm{E}-07$ & 0.9071 & Tidak signifikan \\
\cline { 2 - 5 } & ART & 0.000398 & 0.1768 & Tidak signifikan \\
\cline { 2 - 5 } & APT & -0.000466 & 0.0604 & Tidak signifikan \\
\cline { 2 - 5 } & INVT & 0.007505 & 0.0000 & Signifikan \\
\hline Intellectual Property & Sales/CGS & 0.232785 & 0.0000 & Signifikan \\
\hline \multirow{2}{*}{$\begin{array}{c}\text { Fixed Asset } \\
\text { Management }\end{array}$} & Sales/Dales & -0.659198 & 0.0000 & Signifikan \\
\cline { 2 - 5 } & FAT & 0.000155 & 0.0382 & Signifikan \\
\hline Weighted Statistic & \multicolumn{5}{|c|}{0.001346} & 0.0388 & Signifikan \\
\hline R-squared & \multicolumn{5}{|c|}{0.463585} \\
\hline F statistic & \multicolumn{5}{|c|}{1.09035} \\
\hline Durbin-Watson Stat & \multicolumn{5}{|l|}{} \\
\hline
\end{tabular}

Sumber: hasil output Eviews 
Berdasarkan Tabel 2, tampak bahwa customer relationship yang diukur dengan rasio sales/advertising dan account receivable turnover (ART) berpengaruh positif tidak signifikan terhadap penciptaan nilai (creating value.) perusahaan Supplier relationship yang diukur dengan account payable turnover (APT) juga berpengaruh negatif tidak signifikan terhadap penciptaan nilai perusahaan, sedangkan yang diukur dengan inventory turnover (INVT) dan sales/cost of good sold (CGS) berpengaruh positif signifikan terhadap penciptaan nilai. Intellectual property yang diukur dengan rasio selling general and administrative expenses $(S G A) /$ sales berpengaruh negatif siginfikan terhadap creating value, demikian juga fixed asset management yang diukur dengan rasio sales/depreciation (DEP) dan fixed asset turnover (FAT) berpengaruh positif signifikan terhadap creating value.

Nilai koefisien derterminasi yang tampak pada $\mathrm{R}^{2}$ sebesar 0.4635 berarti sebanyak $46.35 \%$ variabel creating value dapat dijelaskan oleh variabel bebas yaitu competitive advantage yang diproksikan oleh customer relationship, supplier relationship, intellectual property dan fixed asset management, sedangkan sisanya sebesar 53,65\% dipengaruhi oleh variabel lain diluar variabel bebas yang digunakan dalam penelitian ini.

\section{Pembahasan}

Supplier realationship yang diukur dengan inventory turnover (INVT) berpengaruh positif signifikan terhadap creating value. Hal ini terjadi jika perusahaan dapat menjalin hubungan baik dengan pemasok. Dengan demikian semakin tinggi rasio inventory turnover menunjukkan semakin baik hubungan perusahaan dengan pemasok .Hasil penelitian ini sejalan dengan hipotesis dan penelitian Liou \& Tang (2009) serta penelitian Lin \& Huang (2011).

Demikian pula dengan rasio sales/cost of good sold (CGS) yang berpengaruh positif signifikan terhadap creating value. Semakin tinggi rasio ini, menunjukkan bahwa perusahaan memiliki hubungan baik dengan pemasok, sehingga perusahaan dapat memperoleh bahan baku yang baik dengan harga yang relatif murah, dan mampu bersaing dengan perusahaan lain. Hal ini sesuai dengan hipotesis penelitian dan hasil penelitian Liou and tang (2009) yang menyatakan bahwa supplier relationship merupakan faktor penting dalam pengelolaan cost of good sold yang efektif dan efisien, sehingga dapat meningkatkan penjualan.

Intellectual property sebagai proksi dalam mengukur competitive advantage hanya memiliki satu indikator yaitu rasio selling, general and administration expenses (SGA)/sales. Hasil penelitian menunjukkan bahwa rasio selling, general and administration expenses (SGA)/sales berpengaruh negatif signifikan terhadap creating value. Hal ini berarti semakin rendah rasio general and administration expenses (SGA)/sales semakin tinggi kemampuan manajemen perusahaan dalam mengelola intellectual property secara efisien, tanpa memengaruhi proses produksi, sehingga tetap dapat mempertahankan atau meningkatkan penjualan dan pada akhirnya menciptakan nilai bagi perusahaan. Hasil penelitian ini sesuai dengan hipotesis dalam penelitian ini dan hasil penelitian Liou and Gao (2011), yang menyatakan bahwa intellectual property yang berorientasi pada produk seperti kompetensi teknologi dan pengembangan sumber daya manusia yang baik memberikan porsi yang besar terhadap peningkatan penjualan. Demikian pula dengan penelitian Liou and Tang (2009) menunjukkan rasio general and administration expenses (SGA)/sales berpengaruh nagatif signifikan terhadap penciptaan nilai, karena saat perubahan kondisi pasar yang dinamis, 
perusahaan yang memilki intellectual property yang yang tinggi lebih mampu bersaing dalam industri.

Competitive advantage yang diukur dengan fixed asset turnover (FAT) berpengaruh positif signifikan terhadap creating value. Semakin tinggi fixed asset turnover semakin efisien perusahaan dalam mengelola aset tetap, sehingga semakin tinggi peluang perusahaan untuk menghasilkan pendapatan dan kemampuan perusahaan untuk menciptakan nilai bagi perusahaan dan pemegang saham. Hasil penelitian Liou \& Tang (2009) menyimpulkan hal yang sama, bahwa kemampuan perusahaan untuk mengelola aset tetapnya memengaruhi penciptaan nilai bagi perusahaan dan pemegang saham. Hal ini juga didukung oleh Lin \& Huang (2011) dalam penelitiannya pada perusahaan semi konduktor yang menyatakan bahwa pengelolaan aset tetap merupakan faktor penting dalam industri manufaktur yang padat modal.

Rasio sales/depreciation ( $D E P$ ) juga berpengaruh positif signifikan terhadap creating value. Halini karena menunjukkan bahwa menejemen perusaahaan mampu mencapai volume penjualan yang relatif tinggi terhadap beban penyusutan aset tetap yang dialokasikan pada harga pokok penjualan. Hal ini didukung dengan mulai membaiknya kondisi ekonomi pada tahun 2010 dan 2011, sehingga perusahaan yang padat modal dapat meningkatkan volume produksi dan penjualan dengan menggunakan aset tetap dengan cara yang lebih efisien. Hasil penelitian ini sejalan dengan hasil penelitian yang dilakukan oleh Liou and Tang (2009) dan penelitian Lin and Huang (2011)..

\section{SIMPULAN}

Berdasarkan hasil analisa yang telah dilakukan, maka dapat diambil kesimpulan sebagai berikut:

1. Customer relationship yang diukur dengan account receivable turnover dan sales/advertising expenses, berpengaruh positif namun tidak signifikan terhadap creating value.

2. Supplier relationship yang diukur dengan inventory turnover dan rasio sales/cost of good sold berpengaruh signifikan terhadap creating value, tetapi tidak signifikan ketika diukur dengan account payabel turnover.

3. Intellectual property terbukti dapat memberikan keunggulan bersaing melalui kemampuan manajemen perusahaan dalam mengelola selling, general dan administration expenses secara efektif dan efisien sehingga dapat menciptakan nilai bagi perusahaan.

4. Fixed asset management baik yang diukur dengan fixed asset turnover maupun rasio sales/depreciation yang dikelola dengan efektif dan efisien terbukti dapat meningkatkan creating value perusahaan manufaktur.

\section{DAFTAR PUSTAKA}

Aaker, D.A. 1989, Managing Assets and Skills: The Key to A Sustainable Competitive Advantage", California Management Review, vol. 31, no. 2, pp. 91-106

Ajija, Shochrul R, Dyah W.Sari, Rahmat H Setianto, martha R.Primanti. 2011. Cara Cerdas Menguasai Eviews. Penerbit Salemba Empat. 
Anderson, E., Fornell, C. and Mazvancheryl, S. 2004, Customer Satisfaction and Shareholder value, Journal of Marketing, Vol. 68 No. 4, pp. 172-85.

Andras, Trina Larsen dan Srini S. Srinivasan. 2003. Advertising Intensity and R\&D Intensity: Differences across Industries and Their Impact on Firm's Performance, International Journal of Business and Economics. Vol 2 , No. 2, pp 81-90.

Barney, Jay B and William S. Hesterly. 2012 Strategic Management and Competitive Advantage. Concepts and Cases, International Edition,. Fourth Edition. The United State of America.

Bowman Cliff and Veronique Ambrosini. 2007. Firm Value Creation and Levels of Strategy Management Decision. (vol.45, No.3): 360-371.

Brigham Eugene F, Joel F. Houston. 2005. Fundamentals of Financial Management, ninth Edition Harcourt College Publisher, USA.

Brigham, F Eugene and Philip R. Daves. 2004. Intermediate Financial Management, Eighth Edition, International Student Edition. South Western, United States of America.

Cao, B., Jiang, B. and Koller, T. 2006. Balancing ROIC and Growth to Build Value. McKinsey on Finance, 19, 12-16.

Chan, Louis K.C, Josef Lakonishok and Theodore Sougiannis. 2001. The Stock Mareket Valuation of Research and Development Expenditures. The Journal of Finance, Vol LVI No. 6, pp. 2431-2456

Dossugi, Samuel. 2009 Analisi Faktor-Faktor yang Mempengaruhi Penciptaan Nilai di Bursa Efek Jakarta. Journal of Applied Finance and Accounting vol. 2 no. 1 (Nov. 2009).

Grant, R. 2008. Contemporary Strategy Analysis. Malden, MA: Blackwell Publish

Hitt, Ireland and Hoskison. 2005. Strategic Mangement, Competitiveness and Globalization: Concept and Cases. 6th edition. Thomson, South-Western

Horne, James C. Van dan John M. Wachowicz,JR. 2009. Fundamental of Financial Management, 12th edition. Salemba Empat, Jakarta

Jiang, Bin and Timothy Koller, 2007. "How to choose between growth and ROIC?" The McKinsey Quarterly, pp 1-4

Koller, T., Goedhart, M. \& Wessel s, D. 2005. Valuation: Measuring and Managing the Value of Companies. McKinsey \& Company, 4thed. , John Wiley \& Sons.

Kuncoro, Mudrajad. 2006. Strategi Bagaimana Meraih Keunggulan Kompetitif Penerbit Erlangga, Jakarta.

Lev, B. and Zambon, S. 2003 "Intangibles and Intellectual Capital: an Introduction to a Special Issue”, European Accounting Review, Vol. 12 No. 4, pp. 597-603. 
Lin, Chiun-Sin and Chih-Pin Huang. 2011. Measuring Competitive Advantage with an AssetLight Valuation Model. African Journal of Business Management (vol 5 no.13): 5100-5108.

Liou, Fen-mai,Eing-chan Tang. 2009. Competitive Advantage, Value Creation and Du pont Identity. The Business Review, Cambridge. (Vol 12, No. 2.): 127-132.

Liou, Fen-May and Yuan-Chuan Gao. 2011. Competitive Advantage in The Online Game Industry in Taiwan. (vol.4 no.2): 136-154.

Palepu, Krishna G, Paul M.Healy. 2008. Business Analysis \& Valuation: Using Financial Statements, Fourth Edition. South-Western, USA.

Porter, Michael E. 1980. Competitive Strategy, Techniques for Analyzing Industries and Competitors. USA, Macmilan.

Riyanto, Bambang. 2001. Dasar-Dasar Pembelanjaan Perushaan. edisi 4, BPFE Jogyakarta. Simchi-Levi David, Philip Kaminski, Edith Simchi-Levi. 2008. Designing and Managing The Supply Chain. Concepts, Strategies, and Case Studies. Third Edition. McGrawHill/Irwin, United States of America.

Spulber, Daniel F. 2009. Economic and Management of Competitive Strategy. World Scientific, Singapore.

Sudana, I Made. 2011. Manajemen Keuangan Perusahaan,Teori dan Praktik. Penerbit Erlangga Jakarta.

Syamsuddin, Lukman. 2001. Manajemen Keuangan Perusahaan, Konsep Aplikasi dalam: Pernecanaan, pengawasan dan Pengambilan keputusan. Edisi Baru, Raja Grafindo Persada, Jakarta

Tang, E.C. and Liou, F.M. 2010. "Does firm performance reveal its own causes? The role of Bayesian Inference. Strategic Management Journal, Vol. 32 No. 1, pp. 39-57. 